\title{
Bioinvasion, globalization, and the contingency of cultural and biological diversity: Some ecosemiotic observations
}

\author{
Claus Emmeche \\ Center for the Philosophy of Nature and Science Studies, Niels Bohr Institute, \\ Blegdamsvej 17, DK-2100 Copenhagen, Denmark \\ e-mail: emmeche $a$ nbi.dk
}

\begin{abstract}
The increasing problem of bioinvasion (the mixing up of natural species characterising the planet's local ecosystems due to globalisation) is investigated as an example of an ecosemiotic problematic. One concern is the scarcity of scientific knowledge about long term ecological and evolutionary consequences of invading species. It is argued that a natural science conception of the ecology of bioinvasion should be supplemented with an ecosemiotic understanding of the significance of these problems in relation to human culture, the question of cultural diversity, and what it means to be indigenous or foreign. Bioinvasion, extinction of native species, and overall decrease in biodiversity, may go along with decreased cultural diversity; as when the loss of local agricultural traditions lead to genetic erosion. There are possible ecosemiotic parallels between language extinction and species extinction, both being related to globalisation. It is argued that the case of bioinvasion reveals the existence of two kinds of ecosemiotic contingency, (1) evolutionary openended and partly random generation of new species and extinction of old ones; (2) the historicity of culture in general and "culture's nature" specifically in the demarcation of a set of landscapes characteristic to a particular nation and piece of human history.
\end{abstract}

According to the biosemiotic turn in contemporary philosophy of nature, our relationship to nature as human beings is deeply embedded in semiotic processes, characterized by continuity between types of sign (and sign interpretation systems) that are natural and types of sign in- 
terpretation that are cultural. ${ }^{1}$ Hence, it is difficult to say where nature begins and culture stops, and such an attempt at "purifying" what is natural and what is cultural can be critizised as a highly artificial inheritance of Cartesian dualism (cf. Hoffmeyer 1996), historically specific to a "modern" mode of thinking and organizing social life (Latour 1991). Moreover, dualism between nature and culture is incompatible with a foundational concept in biosemiotics, the concept of semiosis in C. S. Peirce and his whole philosophy of synechism, i.e., the doctrine of continuity, according to which the cosmos is only capable of further evolution so far as it "is mind, and so has life" (CP 6.289). From that perspective it is recognized that what we categorize as natural and cultural processes are deeply interwoven and can only in theory be separated - which does not mean that in particular theoretical contexts we are not forced to make such distinctions. Furthermore, "the synechist will not admit that physical and psychical phenomena are entirely distinct [...] but will insist that all phenomena are of one character, though some are more mental and spontaneous, others more material and regular. Still, all alike present that mixture of freedom and constraint, which allows them to be, nay, makes them to be teleological, or purposive" (CP 7.570). The biosemiotic turn in thinking and theorizing about nature and communication, principally based on a Peircean perspective, may also have implications for the pursuit of a truly general ecosemiotics, defined as "the semiotics of the relationships between nature and culture" (Nöth 1996, 1998; Kull 1998) with special focus on nature's role and meaning for humans.

An ecosemiotics must be non-dualist in its outlook and yet, facing concrete problems, it has to acknowledge true differences in the meaning of nature when seen from the point of views of biology and other natural sciences and when studied by various human science approaches focusing on the significance of natural processes for cultural and social practices. There are interesting affinities between ecology and ecosemiotics in theory and practice. Since the so-called global civilization is advancing much more hastily in material than in ethical directions (to put it mildly), ecosemiotics becomes most relevant to the understanding of the many challenges to sustainability in a world in which the cultural, linguistic and biological diversity is seriously threatened. In that sense, ecosemiotics may be important to ecology as a science, as well as relevant for the ecological dimension of politics.

\footnotetext{
${ }^{1}$ See special issues of Semiotica 120(3/4), 1998, and 127(1/4), 1999. See also Nöth (2000) section IV.6 on biosemiotics.
} 
Ecosemiotics includes, inter alia, the study of semiotic aspects of the relations between local human populations and their local ecosystems. As the scope of ecosemiotics is broad, this comprises both the study of anthroposemiotic processes (including mythological, ideological, political, and aesthetic aspects of humans relation to the nonhuman parts of nature), and the study of biosemiotic processes (such as the effect of human intervention both upon the horizontal semiosis between various species in an ecosystem, and upon the vertical or evolutionary semiotic processes). It is important to note that the very distinction presupposes a non-animistic and (partly) scientific world view in which we can distinguish the symbolic meaning that for instance wolves or bears have to us from the semiosic processes involved in the very life of these animals. This is not to say that the very symbolic meaning of animals in an anthroposemiotic context does not play any role in our decisions about conservation strategies for wolves or bears and thus for the continued biosemiosis of these organisms.

The aim of the present study is to present to the ecosemiotic community a case of scientific, social, and environmental relevance, namely bioinvasion as an effect of globalization. It will be noted briefly that there are possible ecosemiotic parallels between language extinction and species extinction, as both are related to globalization. It is important to reflect upon what can be learned from the case of bioinvasion regarding the methods and foundations of ecosemiotics as a field of study.

\section{Bioinvasion - an ecosemiotic disturbance}

Biologically, ecosystems are local systems of communities of plants, animals, and microorganisms and their interactions with the specific physical, chemical, and geological environment. The tropical rain forest in the Amazon area is not identical with the tropical rain forest of central Africa, each large ecosystem has a specific composition and a complicated structure of local habitats or subsystems, each again with a characteristic species composition. Thus, ecosystems have a diversity of species, some of which may be found in a variety of different ecosystems, but many are naturally restricted to a few or one specific kind of ecosystem.

Bioinvasion has come to denote the (intended or non-deliberate) introduction by human activity of non-native species into ecosystems 
in which such species have not been found before, and in which they tend to become invasive, that is, they spread, colonize and become established, often at the cost of the distribution range of some of existing species.

Bioinvasion has not only become a threat towards the local ecological stability of a known local flora and fauna. When Homo transportans, the travelling human, is moving the planet's species of plants and animals all around, it may, as we shall see, influence the core of evolutionary processes. The consequences cannot be predicted precisely, but the overall tendency is clear, that is, to decrease biodiversity, and with it, ecosemiotic difference. But bioinvasion as a problem and phenomenon is not only about what happens in Nature, it is seriously consequential regarding how humans conceive nature and culture. There is even a certain danger that everyday concepts about homely and foreign are being mixed with similar concepts in a scientific-biological version.

The points to be developed more in detail below are these: (1) Bioinvasion on a global scale is an ecosemiotic phenomenon with long term consequences for biological evolution. Bioinvasion can contribute to perturb the balance between two rates: the rate at which new species are formed and the species extinction rate. The net effect will be a decrease in species number and ecosemiotic variety. (2) Evolution takes place in local ecosystems. An ecosystem is more than the sum of its species and is characterized by a complex material and semiotic dynamics. This makes it difficult to predict the effect of disturbances. But for "the worst case" it remains inevitable that increased bioinvasion will globally decrease biodiversity and disturb the evolutionary dynamics. (3) Indigenous, native, and foreign are terms for properties that seem to be used in two quite different spheres: Culturally in the debate in many European countries about the transformation by immigration of demographic relatively homogenous societies into multicultural societies; and "naturally" in the context of nature conservation and bioinvasion. It is crucial to distinguish these contexts and, at the same time, be able to see how they both have their actuality related to the process of globalization. Xenophobia on behalf of $\mathrm{Na}-$ ture may not be misplaced, but the parallel between fear of globalization on the cultural level and fear of bioinvasions in ecosystems should not be politically misused. 


\section{The exotics arrive}

Invasion of foreign species to the local habitats of plants and animals have been called a quiet and unnoticed catastrophe. Many Europeans believe that the giant hogweed or cow parsnip (Heracleum pubescens), introduced from Caucasus, can out-compete local species of hogweed in Central and Northern Europe. The giant herb plant evidently changes some habitats dramatically, though out-competing has not been documented. However, this is only a minor example of a wide-ranging pattern of mixing and blending the planet's local species straining the original environments. It may lead to ecological chaos when exotic organisms suddenly appear at unexpected places and eventually spread as a pest because no natural enemies, as in the exotic's native surroundings, dampen the population in the invaded areas.

Numerous examples have been reported, both aquatic and terrestrial. A well-known and illustrative case is the introduction into Lake Victoria in the 1950s of the Nile Perch, with devastating consequences for the endemic ${ }^{2}$ species of cichlids. The Nile Perch is a predator fish that can grow up to 2 meters long. The first decades of its life in the lake passed on quite smoothly, but in the 1980s its population density exploded. The native species vanished, and a survey concluded that some 200 species had disappeared completely (Goldschmidt et al. 1993). This did not end the drama. Around 1990, the water hyacinth (Eichhornia crassipes), a native plant of the Amazon Basin brought to Africa as a pool ornament in the nineteenth century, arrived at Lake Victoria. It is one of the world's fastest growing plants, and in the absence of fungi and insects that feed on it and the presence of enough nutrients, it covers the waters by dense mats. By 1996 it was strangling $90 \%$ of the lake's shoreline, completely changing the sea ecosystem and deoxygenating the waters. One result was that by 1997 , "ten thousands of fishing families had lost their livelihoods to the weed; many had abandoned the lake and moved into the city" (Bright 1999: 90).

${ }^{2}$ Endemic, i.e., found only at this local site and nowhere else. An amazing high percentage, $44 \%$ of the known global biodiversity of plants and $35 \%$ of all non-fish vertebrates are endemic to just 25 separate "hotspots" on $12 \%$ of the earth's surface. These areas are under acute threat, principally through forest clearing — overall, only about $12 \%$ remains in its original state (see Kitching 2000 ). 
Bioinvasion is particularly serious in many small islands like Hawaii, which is home to some of the most unique and endangered rain forest ecosystems on earth. Extreme isolation, diversity of habitat zones, and a moist tropical climate have given rise to very high rates of endemism in these islands. Over $90 \%$ of the species native to Hawaii are endemic. On the island of Maui, many species are unique to Haleakala volcano or the west Maui mountains. Today Maui is home to 91 threatened, endangered or proposed endangered species. The continued invasion of Maui by alien (non-native) plants, animals, insects, and microorganisms poses the greatest threat to the future existence of these native ecosystems (Bright 1999). Specific information about bioinvasion can be found on many web sites (such as the Global Invasive Species Programme website, GISP 2000).

Bioinvasions can have different causes, most of which can be traced back to the breakdown of natural barriers between ecosystems due to globalization. Globalization is here understood in its sociological sense as the transgressing expansion of the Western way of life (including commerce, political, economical, social, and communicative structures, functionally partitioned institutions, and an outlook on nature predominantly oriented at control) at the expense of more traditional or premodern forms of life. A marker of globalization is "the intensification of world-wide social relations which link distant localities in such a way that local happenings are shaped by many miles away and vice versa" (Giddens 1990: 64). Another way to put it is to assert that globalization is the extension of imperialism, capitalism, and the world market by new means; the ecosemiotic effect of which is to extend the symbolic domain of exchange value into new areas of the semiosphere. Money as a symbolic exchange system has the social advantage that otherwise incommensurable phenomena may be compared. But the systematic abstraction from use value (and intrinsic value) involved in exchange may have the drawback of creating a risky non-knowledge of the effects of transplanting the things exchanged, especially when such "things" are not just dead artefacts but organisms with a life and environment of their own.

As ecosystems are extremely complex, it is notoriously difficult to predict the risk of real invasion and unbalance by the deliberate introduction of a new species (as in horticulture and agriculture), or by accidental "leakage" or other forms of unintentional importation. The crypto-ecosemiotician Gregory Bateson often emphasized that the real ecological unit was not the organism as such, but the relation between the organism and its environment (Bateson 1972). Without its envi- 
ronment, including its Umwelt, an animal is not real, and when transplanted to a different environment, we are dealing with a quite different and potentially risky unit.

It is a general feature of scientific findings that the answers are far from definitive. This is especially true in the context of bioinvasion where knowledge is lacking on several levels about ecological factors influencing the growth of populations such as climate, competition, the ecosystem's potential for new niches, stability and diversity of ecosystems. At the greater time scale, the very process of evolution may be affected if all is finally squeezed into the same juice of one single hyper-ecosystem.

Scientifically bioinvasion must be seen as a (human-created) phenomenon of nature, deeply related to human forms of life and understanding. It affects the environment, but is also about a part of the anthroposemiotic Umwelt - of our conceptions and presuppositions. Combating bioinvasion is not a form of cultural xenophobia, though it might be mistaken for that. Thus, one should also analyse the ecosemiotic question of possible parallels between the fear of foreign species in nature and the fear of people from other ethnic groups; especially in an atmosphere where terms like xenophobia, tolerance, and political correctness are degenerating to mere rhetorical devices.

\section{Finding balance in the dynamics of nature-culture hybrids}

Bioinvasion threatens biodiversity. The variety of species in an ecological society shrinks if exotic species invade and press the native ones, eventually so much that they become extinct. This kind of pollution of flora and fauna is not the same as spilling oil that is diluted with time. The perturbation of an existing and delicate balance between local species of a biological community may irreversibly change the characteristics of an ecosystem such as a forest, a bog, a swamp or a marine area.

One could ask, sceptically, whether nature as such is not always dynamic and ever changing, and whether bioinvasions or immigrations of non-local species is not a far more permanent and natural phenomenon in ecosystems, following, for instance, climatic fluctuations. Climate change has always favoured some species at the ex- 
pense of others. We as humans may be concerned if species appreciated by us are driven back, but honestly, does Nature care?

The answer is, briefly, that no, nature is dynamic, but yes, nature is not careless or indifferent. The argument is one that relates ecosemiotics, biosemiotics, and bioethics to each other. As a premise it is crucial to distinguish nature as merely matter (as often supposed to be the point of view of physics, though this is a crude simplification) from nature as complex, living dynamical systems (systems realizing purpose, semiosis, intentionality, and value). Humans can manipulate and partly control living nature, but unrestricted attempts at mastery over nature rebound on humans in the form of unpredictable and undesirable side effects concerning health, economy and beauty. Some philosophers have argued that when someone has polluted a lake, nature is not brought out of balance - the stinking algae puddle that was formerly a lake has simply achieved another balance (Thyssen 1982) - thus trying to locate all value on the human side of the nature-culture divide; seeing humans as primarily belonging to a "second nature", and in that sense always transcending the "first nature" of physical and biological systems. Structurally, this position is similar to some versions of social constructivism claiming that the fact of pollution is a fact manufactured by the fabric of science within a particular cultural setting of human values with no privileged claim to universality or truth (for a critical survey of different forms of social constructivism, see Collin 1997). There is no question here of denying that "pollution" is partly a normative concept. But against the provoking view that there are no objective (person- or culture-independent) preferences for the clean lake, one should remember that it is basic (also to all environment protection work) that we can distinguish between nature as merely matter (careless about pollution) and nature as living systems, whose parts are vulnerable and who has (and makes) meaning - both biologically for the involved species themselves (Hoffmeyer 1996) and practical, aesthetic, and ethical signification to us as humans: neither salmons or salmon fishermen are indifferent to pollution.

Organisms have their own preferences, they prefer certain habitats to others. Values in this elementary sense are located in nature. An advantage concerning this simple point is that it escapes endless and abstract hair-splitting on whether values are always set by humans or whether nature can have intrinsic values, because most people will recognise that each individual species of plants or animals prefers and 
(in that pragmatic sense) "values" particular places to be in or grow in a heterogeneous environment.

Even though "original" nature in industrialized countries is becoming very rare or even an idealization, and even though a landscape is a mix or a hybrid (sensu Latour 1991) of natural processes and cultural disturbances, it is to a high degree meaningful to talk about animals, plants, and microorganisms as beings that partake in larger wholes, ecosystems, which have qualities of both a natural and cultural kind. A lake can loose so many of its qualities that organisms that formerly lived there search other places (if they can), or simply become extinct. If so, the ecosystem will also appear of less value to us. In that very basic sense, all ecosystems are also ecosemiotic systems with intrinsic values.

\section{Knowledge of ecosystems}

Classical ecology focused on dynamical properties of especially "natural" ecosystems (not influenced by human activity), including the general processes of speciation and extinction. Modern ecology continues this tradition, but also investigates that special hybrid dynamics of spontaneous, deliberate, and unintentional processes unfolding when humans' material use of natural resources intensifies. What is highly worrying is not species extinction as such, for during the whole history of life on the planet, new species have evolved and others have gone. It has been estimated that over $99 \%$ of the species that ever existed on earth have become extinct (Stanley 1998). This is the rate at which biodiversity is generally deteriorated, which is worrying because manmade extinction highly exceeds the rate at which evolution creates new species at the geological time scale. The number of species is related to the number of qualitatively fitted ecosystems.

The quality of ecosystems can be conserved, increased, or reduced, or completely threatened, and bioinvasion has shown to be an often overlooked contributing factor in the general deterioration of biodiversity, both globally and nationally (Hobbs 1989; Drake et al. 1989).

There are much missing in our knowledge of foreign species which appear by the help of humans in ecosystems they would not normally reach and become established. The detection of bioinvasions often demands careful monitoring to achieve detailed data about the actual species composition of various types of ecosystems. As the total size 
of the population of a given species is subject to natural fluctuations - because of climatic variations, fluctuations in populations of other (predator, prey or parasite) species, nutrient supply and so forth - this demands often data for long periods of time. Even in a small country like Denmark where wildlife and wild vegetation have been mapped and monitored reasonably in detail, more fine - grained monitoring programmes are needed, the same is indeed still more true for larger nations.

\section{The species as a part of a whole with systemic properties}

Saying that bioinvasion is an ecological problem points to the fact that what is effected in a local landscape by the exotics is not only the population sizes of the individual species but systems of species ecosystems. Properties of ecosystems do not reduce to properties of the organisms of each species. The diversity of species, the carrying capacity of the system and its balance (or temporary stability) are some of the properties that biologists fear to be threatened by bioinvasion, but one may also add the experiential qualities we as humans associate with wild or semi-wild nature. Even though there have been considerable arguments and scientific controversy within ecology about how precisely to define concepts like biodiversity, ecological balance and stability, there are reasons for keeping in mind the general reality referred to by these notions and their ecosemiotic dimensions. This can be summarized in four items.

1. In analogy to an organism, an ecosystem has a certain thresholds of tolerance for specific parameters (e.g., temperature, nutrients, toxic chemicals). Within these thresholds, the organisms of a particular species and their environmental relations may adapt to perturbations, but if the changes become too powerful, the system is pushed beyond its "homeostatic plateau" (that area or interval of tolerance between the higher and lower parameter values within which adaptation is possible), and the system is transformed to a quite different kind of ecosystem. The system has been changed - or destroyed. Pollution of a lake with artificial fertilizers is a well-known example, but also the introduction of a foreign species into a lake can, as we have seen, push the lake beyond its original dynamics and make the ecosystem of a different kind. For instance, the omnivorous pollution-tolerating common 
carp (Cyprinus carpio) was introduced to Europe from Asia by the ancient Romans, and have during the late nineteenth and early twentieth century been introduced to many other places of the world, including the Southern United States, where it has transformed many clear lakes to algal ponds, displacing local fish species (Courtenay et al. 1992).

(Excursus: We see here that bioinvasion and globalization are processes as old as civilization, indeed an aspect of it, but only when such processes are becoming more fully realized can we grasp or develop, in an almost Hegelian sense, the full implications and meaning of these concepts. This is an ecosemiotic point. When the civilizing process extends to Nature's own "self-organizing" systems, it may have catastrophic consequences when another developmental logic is imposed on natural systems. Natural systems have natural barriers. The nature of capitalist civilization is breaking down all barriers for the sake of free exchange of "goods" and resources.)

Changes from one ecosystem to another may be described on an abstract level by the language of complex dynamic systems. ${ }^{3}$ The differences between different attractors in the whole "ecological state space" (that may be described quantitatively within this physical approach by simulating some mathematical models of particular systems), and the eventual existence of stable periodic, quasi-periodic, or chaotic attractors within some parameter range, may throw some light on issues of predictability and stability of ecosystem behavior; however, it is also important to relate such approaches to the communicative or semiotic network that are part of emergent biological processes that gives coherence and stability to ecosystems.

2. Biodiversity is a measure for the richness, variety, and multitude of organisms in an ecosystem. Monocultures like a cotton field have only few other species than the one species cultivated (by use of herbicides and eventually gene-spliced herbicide resistance in the crop); a pine plantation or a rubber estate have some more species, and a wild deciduous forest have far more. The concept of biodiversity covers the ecosystem level (the variety of ecosystems in a landscape), the species level (within an ecosystem), and the level of genetic variation within a single species. Evidential signs indicate that next to the destruction of habitats, bioinvasion is what contributes most to the erosion of biodiversity at all three levels (Vitousek et al. 1997). Furthermore, the de-

\footnotetext{
${ }^{3}$ For a general survey on notions of complexity, see Emmeche (1997). A popular introduction to "the sciences of complexity" is Coveney and Highfield (1995).
} 
struction of habitats makes it easier for introduced species to become invasive; colonizing species can profit from the decreased level of competition which is an effect of habitat destruction (IUCN 1999). The number of species in an ecosystem is only a rough measure of biodiversity, as this concept from a biosemiotic point of view must involve qualities related to the unique pattern of relations between different species in their total activity. This activity is not simply ruled by physical laws in the usual sense, but is guided by the final causality of sign action. For instance, in the tropical forest one often finds a relation between species in a pattern like this: species $A$ depends on species $B$ (eventually plus a few more), $B$ depends on $C$, and $C$ depends on $D$ and $D$ depends on $E$ - that is, chain-like structures of relations with interconnections between the chains. The loss of a single species may effect all the following in the chain.

3. Stability of ecosystems, understood as a kind of buffering capacity against perturbations, has often been claimed to be related positively to a system's biodiversity. There was a tradition in ecology in the 1970 s according to which high diversity guaranteed high stability. More recent research in ecology has seriously questioned this assumption and has shown that this relation is not unambiguous, but can only be perceived a rule of thumb with many exceptions (Ludwig et al. 1997; Doak et al. 1998). The insight of "chaos" in physics (non-linear dynamics) made ecologists realize what was overlooked before, namely that (1) even in high-diverse systems small changes, such as the elimination of a single species, may create a whole cascade of effects so that some form of "butterfly effect" is actualized: a little change may have extreme effects. (2) In practice it will often be impossible (due to non-linearity and extreme sensitivity on initial conditions) to predict whether there will be a cascading effect or not, which should happen if a so-called "key species" of the ecosystem is involved (this concept is also debated, however). The lesson of chaos is a high degree of modesty regarding our capacity to predictive control of ecosystems.

4. Evolution needs heterogeneous environments. Nature has, by spontaneous processes, evolved new species since the first life made its appearance here on the Earth for approximately 3.800.000.000 years ago. Geology, climate, and other physical processes have contributed to create the environmental heterogeneity - which of course has physical as well as semiotic aspects - such as the difference between land, sea, lakes, mountains, and other important — we might call them primary - differences. Upon this base of primary heteroge- 
neity, there exist layers upon layers of bio-generated heterogeneity which have been crucial to the evolution of new species. The combination of physical and biotic factors leads, by nature's tendency to complexify and take new habits, to the creation of a very high number of different habitats. Both the primary geophysical-geographical and the additional layers of heterogeneity create barriers between the species. (In an abstract sense similar to the creation of barriers between different newly generated syntactic and semantic habits in the evolution of different languages, such as in pidgin languages; but of course, this is just an analogy not to be pursued further here.) Geographical and other forms of isolation are among the important preconditions for speciation - Darwin's finches are a well-known example. An ecosystem is at once open to energy (and to some extent to matter) and relatively organizationally closed regarding its species. There exist characteristic and relatively stable communities (of plants and animals) in various ecosystems. ${ }^{4}$ Evolution and environmental heterogeneity are the historical foundation for the generation of biodiversity. Globalization and bioinvasion threaten to dissolve this fundament. The increased mobility of local species "hitchhiking" on humans may lead to decreased variety of different specific local ecosystems. What looks like increased "ecosemiotic freedom" so to speak, becomes in fact increased uniformity and a standardization of nature. An example are the aquatic communities of invertebrate animals found within the big harbours all over the world and in nearby coastal areas, where one finds the remarked tendency that these ecosystems are becoming more and more similar to each other, among other things, because of intake and release at such places of huge amounts of ballast waters in big tankers and other transport ships.

Thus, biodiversity can no longer be considered simply as a question about the number of species in a local ecosystem. There are examples of introduced species that have enriched the local habitat without becoming invasive, but the existence of non-linearity ("chaos") in com-

${ }^{4}$ One of "the earliest clear recognitions of the existence of particular assemblages of different species" (Kormondy 1965: 118), i.e. the community concept in ecology, was Edward Forbes, who in 1844 published a "Report on the Mollusca and Radiata of the Aegean Sea, and on their distribution considering as bearing on geology" (reprinted in Kormondy 1965). The word ecology is usually credited Ernst Haeckel (in 1865), but according to Kormondy (1965: xiii) it was a Reiter who first formed the term one year before Haeckel. Communities in ecology were probably first systematically studied by the botanist Eugen Warming. 
plex systems and the historical examples of exotics that have exploded in population size only after a long period of low level density in the new area should keep us from experiments, remembering how extremely difficult, if not impossible, it would be to predict those introductions that are risky and those that are not (i.e., not disturbing the balance between the indigenous species). Each owner of a garden may like to design a local paradise, but the ecosemiotics of gardening and similar projects cannot be quite so innocent as before the era of globalization.

It is important to realise that a species is not simply a species. The species is part of an ecological context, a totality, in which it systematically plays a role in that particular ecosystem. Being a part of a whole, it is in this case to a high degree the whole which imprints upon the species its characteristic ecological properties. An analogy can be made from the relation between an enzyme and a cell. Looked at purely chemically, the enzyme is simply a protein compound with a particular three-dimensional structure, but in the cell's metabolism, the enzyme has a specific function due to the relation between its form and the set of actual specific substrates. Function is here an emergent property (a property of a higher order than simply a chemical property), that is, the role of the enzyme cannot be characterized on the protein-level, because the role is a relational property determined by the whole network of other substances in the cell with particular functions. In analogy, a species is something one might characterize purely anatomically and morphologically, but as part of an ecosystem the species has a functional role in the network of relations with other species in the ecosystem. Functionality (in ecology, or in molecular biology, or even in ecosemiotics) is thus be regarded as involving final causality (a purpose-like form of causation, sensu Peirce), and more to the point, this final causation (Santaella Braga 1999) is related to the hierarchical or level-structured organization of life, with emergent properties and a kind of downward constraint (downward causation, cf. Andersen et al. 2000) from the whole to the individual parts.

The function of a species can be more or less decisive for other species and if a species disappears it may have short or far-ranging implications. An example of a little trophical cascade is the introduction of a predator who eats the zooplankton in a lake, which makes the plant plankton bloom, and finally this depletes the water's oxygen resources. Due to its many components, an ecosystem may certainly have possibilities for maintaining its most general functions (e.g., photosynthesis) by regulatory compensation, that is, one component takes 
over if another one disappear (the system has a buffering capacity, see Jørgensen 1997). However, the lessons from bioinvasions have been that the qualitative indicators for a system's stability and identity (such as specific composition of species) are important. It is not insignificant which species in the concrete case are filling out the role as primary producers. The point is that bioinvasion is not about species as single atoms, but about systems with ecological end semiotic properties on different levels. Such systems are at once evolutionary and ecological. The evolutionary consequences of bioinvasion are alarming. As in the risk assessment analysis of atomic nuclear plants, one operates with the worst imaginable case, one should try to include the worst possible consequences of bioinvasion in a global, evolutionary perspective.

\section{Global spread and evolution: the extinction of difference}

Let us invent a little thought experiment. We do not need computers to do the simulation. It is about an extremely simplified and artificial universe, but the claim is that it nevertheless reflects certain aspects of evolution on this planet and the threat against evolution in form of bioinvasion.

We let the evolution in our constructed universe span over three epochs: The original pan-epoch, when the planet's living places are connected and continuous, with very few basic types of ecosystems (somewhat corresponding to the archaic coherent supercontinent Pangaea that existed for about 200 millions years ago). The dynamic splitepoch, where evolution gets speedy after the genesis of great geographical barriers between different regions of the earth (as the planet with the same continents and all that environmental heterogeneity we know today). Finally, there is the inva-epoch, where the barriers dissolve (as with the globalization of today).

(1) In the pan-epoch, the starting state of the system, there are in our little scenario only three ecosystems — defined by basic ecosemiotic differences: mountain /lowland /sea - each with 3 species, in total only 15 species.

(2) Then we let the evolution run for some billions of years. In this new split-epoch both new ecosystems and new species are generated. We get 10 different kinds of mountain-ecosystems, 10 different kinds of lowland ecosystems, and so forth, so now we have in total 30 eco- 
system types, and for each of them there are generated about 50 new species by evolutionary processes like natural selection, organic selection, sexual selection, niche specialisation, genetic drift, and soon. So now our little universe has around 1500 different species in total.

(3) Then comes the inva-epoch, corresponding to the re-creation of a kind of super-continent. For some reason the barriers between the 30 ecosystems are obliterated. The evolutionary forces continue to act, and with them the action of living signs, but in contrast to the splitepoch, where the evolutionary processes in combination with geographical and other sorts of isolation acted to generate new species, the total mix-up following the increased connectivity between ecosystem types results in a competition-dependent reduction, both in number of species and in the number of ecosystem types. First we come down to 700 species, and as some of the extinct species were key species in the ecosystems generated in the split-epoch, the number of types of ecosystems (such as lowland ecosystems) is further reduced, and so on. The result: 15 different ecosystems, each with 9 species, in total 135 species. If we take species number as a measure of biodiversity, the whole story thus goes from 15 up to 1500 and then down to 135 species.

Now one should not take this thought experiment more seriously than it is: A pedagogical illustration of the connection between the evolutionary process and the (physical, climatic, geographical and semiotic) barriers between habitats, which is a very important precondition for the biodiversity on earth. A less dramatic scenario could have illustrated that biodiversity can grow locally but diminish globally (for instance of each ecosystem could sustain 60 species after the invasion, but it was more or less the same species all over). It is certainly possible to elaborate on the thought experiment, simulate mathematically sophisticated models, make the conditions more precise and realistic, run the interactions in a more complicated way, and experiment by varying the parameters and preconditions (see, e.g., Kaufman et al. 1998). It is beyond this note to discuss such models here, and it will hardly change the basic point, namely that we can point to three kinds of states or phases, the third one being ecosemiotically unattractive, and that we have certain possibilities of avoiding it or at least slowing down the rate at which we approach it. The phases can also be called:

Pangaea: The youth of multicellular life, with few ecosystems and few species. 
Gaia's many continents and heterogeneous systems, with high biodiversity. Now.

Hyperpangaea appears: A hyper-ecosystem with a lower global biodiversity. Tomorrow?

In the actual history of life there have sometimes appeared situations that on a similar scale may be compared to the generation of a hyperpangaea (or biological "globalization"). For about 70 million years ago a land was created connection via the Panama isthmus between the formerly isolated North and South American continents. Before the collision of these continents, since the break-up of Pangaea (for about 200 million years ago), evolutionary processes had generated a series of parallel forms of marsupials in South America and placental mammals in North America. The placental sabre-toothed tiger and the marsupial sabre-toothed tiger were thus geographically isolated, but occupied parallel ecological niches. After the establishment of the land connection - and the following "natural" bioinvasion - occurred a temporary increase, during the very exchange period, in the number of mammal families (in North America from 25 to 35, in South America from 30 to 40), but this richness was short-lived. After this period, the number of families was stabilised on each continent at the old level. However, it was not the same families as before, and in total, the number decreased. Especially in South America, the original fauna faced hard challenges, and about $40 \%$ of the original mammal families went extinct as a consequence of competition with the species from the north (Heinberg 1987; May 1978). This indicates that the possible niches for mammals on the two continents were generally filled, and that the ecological parallels between the placental and marsupial mammals were real, which was why co-existence was not possible.

It does not take much ecological imagination to conceive of the evolutionary consequences of a total globalization at present. Phase 2 and 3 can be viewed as the extremes on a scale on which we move daily a little step in the wrong direction.

\section{Bioinvasion as a cultural threat}

The expanding world market redistributes enormous quantities of commodities, labour, and capital. We cannot return to the time before globalization, and few want to decrease the commercial, scientific, and cultural exchange between nations. But this does not mean that we 


\section{Claus Emmeche}

wish for a world in which all differences have disappeared or all cultures have become one. It should raise concern (not least in semiotic circles) that linguistic diversity is decreasing so dramatically and that the current estimates, based on the present rates of language death, say that only about half the world's 6000 existing living languages will survive the next 100 years (Grenoble \& Whaley 1998; Crystal 2000; Ostler 2000).

Correspondingly, nature's diversity of habitats, species, and local variants of wild or domesticated species are under pressure. Globalization endangers both forms of diversity, and interestingly, there can be connections between conservation of local types of ecosystems and local types of cultures. A threat against one may lead to a pressure on the other and vice versa (Posey 1999; Nettle \& Romaine 2000). For example, genetic erosion will follow from the loss of local traditions of farming or agriculture. The distribution of genetically modified crops is world-wide connected to the extension of industrialized forms of agriculture and cultivation, in particular, when the peasant buys herbicide, herbicide-resistant seed, and artificial fertiliser, and the local varieties gradually disappear. In Northern Europe, the heather and moor lands, the hay harvest meadows, and the commons are examples of culturally affected ecosystems whose existence depend crucially on the specific method of agricultural work that created them.

But should bioinvasion be conceived of at as a cultural menace? If a nation's borders are historically accidental compared to natural borders, one would characterize "the national nature" almost as a social and historical construction to the extent that political and not biogeographical borders determine which species belongs to the flora of Mexico, USA, or Canada, and is represented in handbooks with titles like The Wild Flowers of Canada. (Of course, it is not nature as such, but its representation in books or ideas which is a social construction in this sense. We will bypass the conceptual difficulties with making that distinction between nature in itself and the ways we represent nature.) The ecosemiotics of bioinvasion must thus also be investigated as a cultural phenomenon.

\section{Xenophobia applied to nature?}

Though the term bioinvasion has not yet been adopted in ordinary language, it is easy for lay persons to get a fairly good idea about its 
meaning: "Is it not something that crawls in across the border and expands and that you cannot keep down - quite uncontrolled?". The word evokes the right intuitions. But in some minds who hold themselves to be rather sophisticated, there exists a certain form of carelessness over the quiet disorder of bioinvasions, that has to be commented on, namely a form of carelessness or dereliction that is rooted in a postmodern scepticism concerning all forms of postulates about an original, authentic nature. If there is no such originality (that a sceptic may have good reasons to suspect) then there is nothing that can be invaded or threatened in its authenticity, — seems to be the argument that reduces the increased concern over of bioinvasions as something similar to ethnocentricity and xenophobia transferred to nature - and the whole discussion begins to look like a remix of films such as Jurassic Park and Matrix. Though it is difficult to expect that the very ironic attitude or the shrug of shoulders is something you can argue with, there appears to be the need of repudiating this form of carelessness resting on a fallacy and a general scepticism concerning the reality of an impoverished ecosemiosis.

The answer to the sceptic is that even though it is true that originality and authenticity are highly relative concepts, and to a certain extent illusory in relation to the small spots of "wild nature" found in many industrialized countries, bioinvasions are in no way illusions. They are in fact in the process of changing the ecosystems globally as well as locally. The sceptic may be right in insisting that historically and anthroposemiotically what is counted as "Canadian nature" and thus what is being invaded is merely accidental, however, we must be make more precise in respect what is accidental, accidentiality or contingency means. This clarification, coming from both science and the humanities, is also part of the ecosemiotic analysis of the natureculture hybrids.

The landscapes of a given nation, such as the Danish nature, has to be understood also by taking departure from the ideological aspects of the phenomenon of nationality, including the national landscapes which in Denmark for instance is found depicted by the so-called "golden age painters" (artists, such as C. W. Eckersberg, Chr. Købke, and J. Th. Lundbye from the romantic period in the first half of the nineteenth century). Contemporary research in the science of human history has reached an understanding of the nation and the people as a construction originating at a certain point in history and eventually disappearing again as a coherent project. Connected with the construction of Denmark as a nation is the creation of a national identity, 
which demands a certain consensus about what belongs to the national literature, the treasure of songs, a story of a common history of the people, a folk character, an official national language (uniting or repressing the richness of dialects), and so on. By using the term "construction" it is not claimed that it is something unreal or necessarily made by a set of deliberate decisions, but that one should not take at face value this story about the essence of a national identity (or the idea of a people's united folk character from the time immemorial), and that it is an illusion to believe that it can be excavated and purified. What is at stake is rather a political project in a given historical situation related to the institutional creation of a national state with sharp borders, based on military and economic power, internally in relation to a society's interest groups and externally in relation to the powers of other states. To the national construction belongs also the construction of a national flora and fauna, where the sciences of zoology and botany in the eighteenth and nineteenth centuries map the kingdom's (or the republic's) plants and animals. Later on, in the twentieth century, updated versions of these sciences begin to relativise and deepen the understanding of which species were "original" or indigenous since the latest glacial ages and which were introduced without really altering the common conceptions (or golden age imaginations) of the national nature and its authenticity. In the whole story about the national, there is a point - very central to the question about bioinvasion - where the research in the humanities on the national construction meets scientific research in the generation of the landscapes; the key word here is contingency as a very special form of accidentiality and randomness.

\section{Contingent nature}

Contingency means that something might have been otherwise, but not totally otherwise - it is a special mixture of historical accidentiality and necessity. (Contingency is indeed an aspect of habit taking in Peirce's sense, its category is thirdness, its causality is final, and so, here in this context, it is used to specify more in detail one of the ecosemiotic workings of habit formation in relation to the nature-culture hybrids). To give a picture, contingency is like going through a maze by throwing a coin and let the heads or tails decide whether to go right or left at each crossroads. The route is determined by random 
accidents, but it is not chaotic or completely random; it contains an element of necessity, namely the interplay between the events of casting the coin and the structure of the labyrinth determining which routes are possible in the future.

Contingency may be found in nature as well as in culture. Contingency has been used as a specific concept in evolutionary biology by Gould (1989) to characterize in which sense the individual species, like our own, were not - at the origin of life or of multicellular animals - predetermined to appear as a product of evolution. Had the circumstances been different (such as for instance in the Cambrian explosion of life forms for about 570 million years ago), intelligent life forms might have evolved from molluscs rather than vertebrates (to spell it out, we might have been squids). Similarly, had the geological conditions been a little different than they were during the creation of such a group of landscapes now called Denmark, this country's "national" flora and fauna might have been totally different. Nevertheless there is also lawfulness, regularity, and order in the way the living environment is structured, and one aspect of this structure is the fragile balance of many ecosystems.

In the human context of the history of ideas, contingency is used to denote the lack of stable traditions and the rootlessness of humans in a modern world where the single individual becomes disconnected from an organic community with traditional customs and morals, is liberated, and released, and thereby exposed to an existential vacuum. In this, illusion about a firm cultural anchorage is dissolved in the etching bath of declassification, alienation, and postmodern irony (Thomsen 1988; cf. eventually Rorty 1989). In parallel with this we realise that the landscapes we were used to see as the quintessence of the nation's typical nature (in Denmark the patchwork of beech forests, heather hills, oatfields, meadows and commons) could have been quite different had the history been a little different. Had the Danes been conquered by the Finns two hundred years ago, birch would have been the national tree and beech just a local deviation (counterfactual processes are in fact a serious topic in contemporary history).

The point is not that because a given piece of nature's landscapes is contingent - both in the sense of natural science as a local product of the cosmic evolution and in the sense of the humanities as an ideological construction - we can be careless about bioinvasions. That would be a fallacy of enormous dimensions. Nature has neither biologically nor culturally that constancy and existence-invulnerability that would mean that we could take it for given - nature has become 
vulnerable during the civilizing process - and because of that are we obliged to be particularly attentive towards the connections between humans and nature and the causes of change in these relations. Being contingent, nature - or our national prides - could have been different. That nature which is immediately relevant to us is not cosmos at the birth of the universe or the universe's remote end; it is nature as a coherent system of living ecosystems, which are truly socioecological and ecosemiotic systems, because the landscape is a nature-culture hybrid, a mix of something physical, biological, cultural, and social.

Furthermore, an ecosemiotic systems has its own life, that is to say a certain kind of integrity in the coherent complex of organic, cultural, and social relations, and being alive, it is vulnerable. We have the obligation to try to avoid or diminish unintentional damages on the system following from human activity. Bioinvasion is such a damage. Thus it must be combated, also as a cultural threat against the individual nations' landscapes, but with full consciousness about the contingent aspects of that mosaic of landscape types and nature-culture components that together constitute a nation's "ecosemiosystems". Thus, in particular cases, we will always have to discuss where we will draw the border between wanted and unwanted species, and this distinction is of cultural value though the underlying reality is the historical continuity between all species that make up all biodiversity.

\section{Let it be?}

To recapitulate, globalization is, as any child knows, imperialism's continuation of the extension of the world market by other means, while bioinvasion as an ecological sequel is not a quite new disease. When the European colonizers settled in Africa, South America, or Australia, they had an uneasy feeling or a vague fright of all the unknown and foreign and different in the new colonies' nature, that seemingly made them blind to its other kind of beauty. ${ }^{5}$ They founded acclimatization societies, especially in the nineteenth century, and organized extensive introductions of hundreds of plants and animal

5 Bright (1999: 134) calls it "colonial angst — an anxiety of difference" that is hard to reconstruct today when we can reach to anywhere in the world within 24 hours, but in the early phases of colonial expansion, being in the colonies could be felt like being at the end of the Earth and "could be frightening or repugnant to European sensibilities" (ibid.). 
species from "the civilized world" (North America and Europe), to the colonies in Asia, Africa and Australia. This included putting out such "homely" species as starlings, goats, pigs, and rabbits in these new environments (Crosby 1986). Very often, this had catastrophic consequences for the local indigenous species and sometimes for the farmers themselves, for instance, when the cattle starved and the farmers had to give up their farms under the Australian rabbit plague that endured for almost a century, until the introduction of the Brazilian rabbit virus in the 1950s.

As you look upon nature, so you treat it. Since the invention of agriculture, human beings have been tempted to see every piece of nature as a potential field, plantation or mine, - or like a garden that can be managed by a gardener. Ecosemiotics should help us to understand the limitations of that view of nature and recognise the complexity of the interplay between human activity and ecological and evolutionary processes. We should not be scared about the foreign, but avoid that the culturally foreign is demonized and that the naturally foreign is snatched away from its local contexts. In ecology, certain things are best to be as they are and where they are.

This may sound as mere conservatism disguised in scientific and scholarly arguments, and thus as a case of scientism. However, this is not the case. The ecosemiotics of bioinvasion is a good example of the fact that we may not always advance in understanding by imposing old conceptual schemes - like the received ways of distinguish between progressive and conservative or between science and politics on our actual problems.

\section{References}

Andersen, Peter Bøgh; Emmeche, Claus; Finnemann, Niels Ole; Christiansen, Peder Voetmann (eds.) 2000. Downward Causation. Minds, Bodies and Matter. Aarhus: Aarhus University Press.

Collin, Finn 1997. Social Reality. London: Routledge.

Courtenay, W. R.; Williams, J. D. 1992. Dispersal of exotic species from acquaculture sources, with emphasis on freshwater fishes. In: Rosenfield, Aaron; Mann, Roger (eds.), Dispersal of Living Organisms into Acquatic Ecosystems. College Park, MD: Maryland Sea Grand College.

Bateson, Gregory 1972. Steps to an Ecology of Mind. New York: Ballantine Books.

Bright, Chris 1999. Life Out of Bounds. Bio-invasions in a Borderless World. Worldwatch Environmental Alert Series. London: Earthscan Publications. 
Coveney, Peter and Highfield, Roger 1995. Frontiers of Complexity: The Search for Order in a Chaotic World. New York: Ballantine Books.

Crosby, Alfred W. 1986. Ecological Imperialism: The Biological Expansion of Europe, 900-1900. Cambridge: Cambridge University Press.

Crystal, David 2000. Language Death. Cambridge: Cambridge University Press.

Doak, D. F.; Bigger, D.; Harding, E. K.; Marvier, M. A.; O’Malley, R. E.; Thomson, D. 1998. The statistical inevitability of stability-diversity relationship in community ecology. The American Naturalist 151(3): 264-277.

Drake, J. A.; Mooney, H. A.; Di Castri, F.; Groves, R. H.; Kruger, F. J.; Rejmanek, M.; Williamson, M. (eds.) 1989. Biological Invasions: A Global Perspective. New York: John Wiley \& Sons.

Emmeche, Claus 1997. Aspects of complexity in life and science. Philosophica 59(1): 41-68.

Giddens, Anthony 1990. The Consequences of Modernity. Stanford: Stanford University Press.

GISP 2000. Global Invasive Species Programme, coordinated by SCOPE (the Scientific Committee on Problems of the Environment), IUCN (International Union for the Conservation of Nature) and UNEP (the United Nations Environment Programme) (http://jasper.stanford.edu/GISP/).

Goldschmidt, Tijs; Witte, Frans; Wanink, Jan 1993. Cascading effects of the introduced Nile Perch on the detrivorous/phytoplanktivorous species in the sublittoral areas of Lake Victoria. Conservation Biology 7: 686-700.

Gould, Stephen Jay 1989. Wonderful Life: The Burgess Shale and the Nature of History. New York: W. W. Norton.

Grenoble, Lenore A.; Whaley, Lindsay J. (eds.) 1998. Endangered Languages: Language Loss and Community Response. Cambridge: Cambridge University Press.

Heinberg, Claus 1987. Økosystemet, struktur og evolution. In: Bonde, N.; Hoffmeyer, J. (eds.), Udviklingsideens Historie. Naturens Historiefortoellere bd. 2. København: G.E.C.Gad, 252-287.

Hobbs, Richard J. 1989. The nature and effects of disturbance relative to invasions. In: Drake et al. 1989, 389-405.

Hoffmeyer, Jesper 1996. Signs of Meaning in the Universe. Bloomington: Indiana University Press.

IUCN, 1999. Draft IUCN Guidelines for the Prevention of Biodiversity Loss due to Biological Invasion. Background paper. Fourth Meeting of the Subsidiary Body on Scientific, Technical and Technological Advice (Montreal, Canada, 21-25 June 1999) (http://iucn.org/themes/biodiversity/sbstta4/guidelines.pdf).

Jørgensen, Sven Erik 1997. Integration of Ecosystem Theories: A Pattern. 2nd ed. Dordrecht: Kluwer.

Kaufman, J. H.; Brodbeck, D.; Melroy, O. R. 1998. Critical biodiversity. Conservation Biology 12(3): 521-532.

Kitching, Roger 2000. Biodiversity, hotspots and defiance. Trends in Ecology and Evolution 15(12): 484-485.

Kormondy, Edward J. (ed.) 1965. Readings in Ecology. Englewood Cliffs: Prentice-Hall. 
Kull, Kalevi 1998. Semiotic ecology: Different natures in the semiosphere. Sign Systems Studies 26: 344-371.

Latour, Bruno 1991. We have Never been Modern. New York: Harvester Wheatsheaf.

Ludwig, D.; Walker, B.; Holling, C. S. 1997. Sustainability, stability, and resilience. Conservation Ecology 1(1): 7.

May, Robert M. 1978. The evolution of ecological systems. Scientific American 239(3): 81-90.

Nettle, Daniel; Romaine, Suzanne 2000. Vanishing Voices: The Extinction of the World's Languages. Oxford: Oxford Univ Press.

Nöth, Winfried 1996. Ökosemiotik. Zeitschrift für Semiotik 18(1): 7-18.

- 1998. Ecosemiotics. Sign Systems Studies 26: 332-342.

- 2000. Handbuch der Semiotik. (2. Auflage.) Stuttgart: Verlag J. B. Metzler.

Ostler, Rosemarie 2000. Disappearing languages. Whole Earth Magazine Spring 2000 (http://www.wholeearthmag.com/ArticleBin/325.html).

Peirce, Charles S. 1931-58. Collected Papers of Charles Sanders Peirce, vol. 1-8 (Charles Hartshorne, Paul Weiss \& Arthur Burks, eds.). Cambridge: Harvard University Press.

Posey, Darrell Addison (ed.) 1999. Cultural and Spiritual Values of Biodiversity: A Complementary Contribution to the Global Biodiversity Assessment. London: Intermediate Technology Publications.

Rorty, Richard 1989. Contingency, Irony and Solidarity. Cambridge: Cambridge University Press.

Santaella Braga, Lucia 1999. A new causality for understanding the living. Semiotica 127(1/4): 497-519.

Stanley, Steven M. 1998. Earth System History. San Francisco: W. H. Freeman.

Thomsen, Hans Jørgen 1988. Frihed og Kontingens: Trcek af Modernitetserfaringernes Historie og Betydning. Arhus: Modtryk [in Danish].

Thyssen, Ole 1982. Den anden natur. Kæbenhavn: Vindrose.

Vitousek, P. M.; D’Antonio, C. M.; Loope, L. L.; Rejmánek, M.; Westbrooks, R. 1997. Introduced species: A significant component of human-caused global change. New Zealand Journal of Ecology 21(1): 1-16.

\section{Биоинвазия, глобализация и возможности культурного и биологического разнообразия - экосемиотические наблюдения}

В статье рассматривается все усиливающеяся биоинвазия (характерное для местных экосистем смешивание видов, вызванное глобализацией) как проблема экосемиотики. В связи с этим вызывает беспокойство явная нехватка знаний о долгосрочных экологических и эволюционных последствиях вторжения чужих видов. Указывается на необходимость дополнения биологического понимания экологии биоинвазии экосемиотическим подходом, который бы связал эту проблему с вопросами чело- 
веческой культуры, культурного многообразия. Биоинвазия, вымирание местных видов и всеобщее уменышение биодевирзитета могут сопровождаться уменышением культурного разнообразия так же, как исчезновение местных земледельческих традиций приводит к генетической эрозии. Между вымиранием языков и биологических видов можно провести экосемиотические параллели, оба феномена связаны с глобализацией. Пример биоинвазии позволяет различить два экосемиотических подхода: 1) эволюционно открытое и местами случайное возникновение новых видов и вымирание старых; 2) маркированность культуры, точнее историчность ощущения природы в культуре, проявляющаяся в характерных "пейзажах" какого-нибудь народа или исторического периода.

\section{Bioinvasioon, globaliseerumine ja kultuurilise ning bioloogilise mitmekesisuse võimalikkused - ökosemiootilisi vaatlusi}

Artiklis käsitletakse üha suurenevat bioinvasiooni (kohalikke ökosüsteeme iseloomustavat, globaliseerumisest tingitud liikide segunemist) kui ökosemiootika valdkonda kuuluvat probleemi. Üheks mureks on teadmiste nappus võorraste liikide sissetungi pikaajaliste ökoloogiliste ja evolutsiooniliste tagajärgede kohta. Osutatakse vajadusele täiendada loodusteaduslikku käsitlust bioinvasiooni ökoloogiast ökosemiootilise mõistmisega selle probleemi seotusest inimkultuuri kultuurilise mitmekesisuse küsimusega, sellega, mida tähendab olla pärismaine või võoras. Bioinvasioon, kohalike liikide väljasuremine ja üldine biodiversiteedi kahanemine võivad käia koos kultuurilise mitmekesisuse vähenemisega samal viisil nagu kohalike põllupidamistraditsioonide kadumine viib geneetilise erosioonini. Keelte ja liikide väljasuremise vahele on võimalik tõmmata ökosemiootilisi paralleele, mõlemad on seotud globaliseerumisega. Bioinvasiooni näide võimaldab eristada kahte ökosemiootilist interpretatsiooni: (1) evolutsiooniliselt avatud ja kohati juhuslik uute liikide tekkimine ning vanade liikide väljasuremine; (2) kultuuri või täpsemalt kultuuri loodustunnetuse ajaloolisus markeerituna mingi rahva või ajalooperioodi tunnuslikes maastikes. 